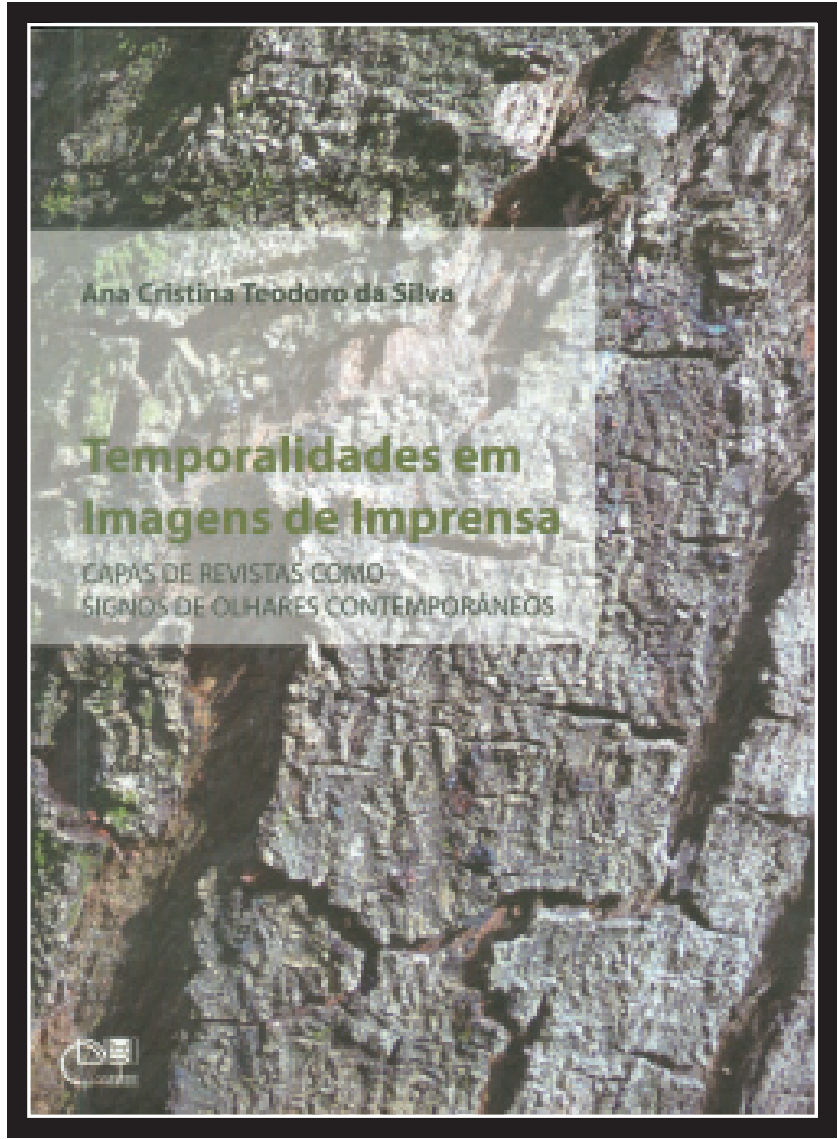

Temporalidades em imagens de imprensa: capas de revistas como signos de olhares contemporâneos, de Ana Cristina Teodoro da Silva. Maringá, Eduem, 2011, $273 p$. 


\title{
A representação da memória do Brasil em capas de revistas
}

The representation of Brazil's memory in magazine covers

\author{
GiseleKrodel Rech*
}

Dois momentos cruciais da história brasileira representados nas capas de três revistas de circulação nacional. É na cobertura das revistas Veja, Manchete e Isto é Senhor, às épocas do Ato Institucional N. 5 (19681969) e das primeiras eleições democráticas pós-ditadura (1989), que se concentra o estudo desenvolvido pela pesquisadora Ana Cristina Teodoro da Silva, da Universidade Estadual de Maringá (UEM), apresentado no livro Temporalidades em imagens de imprensa: capas de revistas como signos de olhares contemporâneos. Segundo a autora, a escolha do objeto de estudo tem uma explicação simples: "As capas são imagens sintéticas, tratam de um tempo condensado, formado por meio de fragmentos, contando com uma leitura rápida."

Depois de estabelecer os recortes temporal e editorial, a pesquisadora adotou a estratégia de descrever cada uma das capas, respeitando a ordem cronológica. Na metodologia analítica, ela levou em conta questões como o uso da fotografia, da diagramação, do emprego das cores, da força das palavras e das expressões corporais - elementos fundamentais no caminho dos grandes meios de comunicação para obter sucesso de alcance e a razão pela qual cada vez mais eles se apoiam na imagem para promover significações. E porque não dizer, perpetuá-las? Afinal, segundo a própria autora, "o trabalho busca a reflexão sobre as imagens da mídia que nos cerca, especialmente no que diz respeito à organização temporal que sugerem". Em suma, o estudo confirma: uma

\footnotetext{
* Graduada em Comunicação Social - Habilitação Jornalismo pela Pontifícia Universidade Católica do Paraná (PUC/PR). Especialista em Gestão e Produção de Rádio e Televisão pela Universidade Tuiuti do Paraná (UTP). Mestranda em Comunicação na Universidade Estadual de Londrina (UEL). Bolsista da Capes (Coordenação de Aperfeiçoamento de Pessoal de Nível Superior). Email: krodelrech@gmail.com
} 
capa de revista pode indicar nuances de uma época ou a representação e o pensamento comum em um determinado período. Porém, essa fala é fragmentada, recortada conforme o interesse - e a versão-de cada veículo.

Ao longo de quatro capítulos a autora aborda as propostas das revistas de "sucesso" - que ela identifica como produtos bem sucedidos , as formas como elas abordam os temas para que chamem a atenção, a importância do corpo nas capas e como essas capas se constituem como elemento de preservação da memória. Com apoio teórico do antropólogo e historiador Eric Hobsbawn, o trabalho começa com a contextualização histórica nos anos 60 e 80 e qual o papel que a imprensa ocupava nesses respectivos períodos.

Infelizmente, Ana Cristina Teodoro da Silva não obteve autorização para publicar algumas imagens (no caso da revista Veja, ela oferece o caminho das pedras, ou seja, o arquivo digital da revista, para a busca das capas às quais se refere no texto). Em contrapartida, como forma de compensação, acabou se esmerando no processo descritivo para permitir ao leitor a visualização mental da capa analisada - o que acaba funcionando de modo eficiente dado o esmero e extrema atenção aos detalhes analisados. Tome-se, por exemplo, a análise da capa da Isto é Senhor de 17 de maio de 1989, na qual ela descreve uma ilustração que coloca o mapa do Brasil escoando sobre um ralo, sob o título "Ninguém segura esse país". Além do sentido provocado pela imagem - o Brasil indo pelo ralo, na representação da crise que assolava o país no final dos anos 80 a autora destaca o uso irônico da expressão cunhada à época do Milagre Econômico Brasileiro alardeado no período da ditadura militar. O processo se faz ainda mais elucidativo com a tabulação dos dados comparativos entre as publicações, centrados nos temas das capas e a forma como cada revista o representa quando optam pelo mesmo assunto para a manchete.

No que concerne aos elementos de significação (forma, corpo, cores e outros), nos quais o estudo se apoia em pesquisadores como Martine Joly e Winfried Nöth, a autora não deixa de fora o leitor e o seu primordial papel no processo comunicativo: "A leitura da imagem dependerá sempre 
do contexto do leitor e suas expectativas serão vitais em tal processo, forjando não um produto final, mas sim um significado que está em movimento." Isso quer dizer que, na construção de sentido buscada pelos editores que fecham a capa, há a preocupação em sensibilizar o leitor, ou melhor, o consumidor do produto revista. Algo que beira, de certo modo, os conceitos de publicidade.

Por fim, ao passo que elenca tantas capas, de três revistas, dos dois períodos - início de vigência do AI-5 e primeira eleição presidencial direta pós-ditadura -, a pesquisa não exclui a referência histórica das capas como parte do registro da memória do país. É nesse momento que se chega ao sentido do título da obra: temporalidades, mesmo que, ao fim e ao cabo, a autora questione o processo na escolha dos fragmentos que são representados nas capas. "O que se reclama, no entanto, é que o discurso das revistas não reconhece que a sua produção explora o que é conveniente no momento", diz. Em resumo, enquanto produto, as revistas se valem de formas que se repetem, informando, sem necessariamente promover reflexão. Por isso, a autora conclui a obra chamando os leitores a refletir sobre as relações entre as formas e os discursos. "Que temporalidades correspondem a quais narrativas? Que ações cada disposição de tempo pode ter como expectativa? De que forma o ritmo acelerado e sintético conta a história? São questões a se pensar". Sem dúvida, Ana Cristina Teodoro da Silva nos dá importantes referências para refletir sobre isso. 